\title{
Evaluation of cytotoxicity and wound healing activity of Avicennia schaueriana in cream
}

\author{
CAROLINE M.I. LOPES ${ }^{1}$, LIRIANE BARATELLA-EVÊNCIO ${ }^{2}$, IVONE A. DE SOUZA ${ }^{3}$, ERWELLY \\ B. DE OLIVEIRA ${ }^{2}$, JÉSSICA G.A. SÁ ${ }^{2}$, MARLLON A.N. SANTANA ${ }^{2}$, PEDRO P. MARCELINO \\ NETO $^{2}$, EDUARDA S. DE SANTANA ${ }^{2}$, LUZIA A. DA SILVA ${ }^{2}$ and JEYMESSON R.C. VIEIRA ${ }^{2}$

\footnotetext{
${ }^{1}$ Programa de Pós-Graduação em Odontologia, Centro de Ciências da Saúde, Universidade Federal de Pernambuco, Avenida Professor Moraes Rego, s/n, Cidade Universitária, 50670-901 Recife, PE, Brazil Avenida Professor Moraes Rego, s/n, Cidade Universitária, 50670-901 Recife, PE, Brazil ${ }^{3}$ Departamento de Antibióticos, Centro de Biociências, Universidade Federal de Pernambuco, Avenida Professor Moraes Rego, s/n, Cidade Universitária, 50670-901, Recife, PE, Brazil
} \\ ${ }^{2}$ Departamento de Histologia e Embriologia, Centro de Biociências, Universidade Federal de Pernambuco,
}

Manuscript received on February 19, 2018; accepted for publication on July 9, 2018

\begin{abstract}
How to cite: LOPES CMI, BARATELLA-EVÊNCIO L, SOUZA IA, OLIVEIRA EB, SÁ JGA, SANTANA MAN, NETO PPM, SANTANA ES, SILVALAAND VIEIRA JRC. 2019. Evaluation of cytotoxicity and wound healing activity of Avicennia schaueriana in cream. An Acad Bras Cienc 91: e20180171. DOI 10.1590/0001-3765201920180171.
\end{abstract}

\begin{abstract}
Avicennia schaueriana is found in Brazilian mangrove coast. The cytotoxicity in vitro of the Aqueous Extract of Leaves of Avicennia schaueriana (AELAs) and the healing activity of the plant in cream on mice skin wounds were evaluated in this study. The cytotoxic evaluation was performed on Vero cells. The healing activity was evaluated on mice treated during 5, 10 and 15 days with cream at 5\%, solution of sodium chloride at $0.9 \%$ and dexpanthenol in cream at $5 \%$. The extract did not show cytotoxicity, but showed mitogenic activity $(100 \mu \mathrm{g} / \mathrm{ml})$. In morphometric analysis, the percentage of wound contraction after 10 days was higher in dexpanthenol group (93.41\%). In 15 days, the lowest percentage of contraction was observed in the dexpanthenol group (94.41\%) and the highest in the AELAs cream group (98.50\%). In histomorphometry the dexpanthenol showed the lowest length of re-epithelialization in 10 days. In 15 days, the AELAs cream group showed $100 \%$ of re-epithelialization. The number of fibroblasts found in AELAs cream group was higher than the saline solution in 10 days. In 15 days, AELAs cream group maintained a higher amount of fibroblasts when compared to the others. A. schaueriana did not show cytotoxicity. Furthermore, topical application of AELAs cream decreased the wound area, stimulated the re-epithelialization and increased the number of fibroblasts. The species $A$. schaueriana could become a topical treatment in tissue repair process.
\end{abstract}

Key words: Avicennia schaueriana, in vitro techniques, re-epithelialization, Vero cells, wound healing.

\section{INTRODUCTION}

Recently, the study of wound healing has become an important topic, as many people suffer from surgical or traumatic wounds every year, with

Correspondence to: Jeymesson Raphael Cardoso Vieira E-mail: jeymesson.vieira@ufpe.br ORCID: https://orcid.org/0000-0003-3793-5830 the imminent need of treatment (Li et al. 2015). The loss of epithelium and the exposure of the connective tissue that characterize the ulcers cause pain and discomfort, affecting the quality of life of the patients (Duarte et al. 2011).

The healing of skin wounds is an intrinsic process of cellular structure reconstructions and layers of lost tissues ( $\mathrm{Li}$ et al. 2015) providing 
a perfectly coordinated cascade of cellular and molecular events that interact to promote tissue repair (Duarte et al. 2011). This process is systemic and dynamic and it is directly related to the general conditions of the organism (Broughton et al. 2006).

The predominant cell population for proper wound healing are keratinocytes, fibroblasts and endothelial cells (Barrientos et al. 2008). Fibroblasts are connective tissue cells responsible for collagen deposition that is required to repair tissue damage (Ross 1969). If there is no repair modifying factor in the wounds, the healing process takes place in an orderly and efficient sequence of events (Campos et al. 2007, Diegelmann and Evans 2004). The wound healing is usually divided into three main phases: inflammatory phase, proliferation or granulation phase and remodeling or maturation phase (Clark 2005, Gurtner et al. 2008). However, some authors, such as Diegelmann and Evans (2004) claim that the healing process is characterized by four distinct and overlapping phases: hemostasis, inflammation, proliferation, and remodeling.

Researches in new medicines that can accelerate the healing process of wounds reduce the painful symptoms and show a great cost-benefit relation have been investigated (Duarte et al. 2011). Studies have suggested that antioxidants may play an important role in the healing process of injuries (Kim et al. 2008).

It is important to highlight that, from the clinical point of view the topical application of medication throughout the entire thickness of the injury is interesting due to the reduction of adverse effects on other organs ( $\mathrm{Li}$ et al. 2015). Topical treatment of ulcers consists of restoring the physiological environment of the wound, to maintain proper humidity, temperature, $\mathrm{pH}$, control of bacterial load, non-viable tissue removal (debridement), odor control, and minimization of the pain and protection of the skin in the affected area. Those conditions, once adjusted, will contribute to the repair and restoration of tissue function (Rolstad et al. 2012).

Plants have been a source of inspiration for new pharmaceutical compounds, which have great contributions to human health because of their therapeutic values (Panda et al. 2009, Vadlapudi 2012). According to the World Health Organization, plants are a source of compounds, which have the ability to combat diseases, with antimicrobial, antiviral and antifungal activities (Gazim et al. 2008, Nascimento et al. 2000). However, herbal products can only be introduced in the society if the laboratory and specific clinical studies prove their efficacy and safety (Agra et al. 2007). Therefore, the proper use of medicinal plants represents an important step and a medication option to be dedicated to the people with the intent to improve their health and quality of life (Silva et al. 2006).

The extracts of different mangrove plants are reported to have several medicinal properties (Agoramoorthy et al.2007, Bandaranayake 1998). In the pharmacological properties of the Verbenaceae family, according to Bandaranayake (1998), the mangrove plants $A$. alba, A. African, A. germinans and $A$. marina show therapeutic compounds that can be used for the treatment of various diseases, including ulcers. Sumithra et al. (2011) showed anti-inflammatory activity of methanolic extract from leaves of $A$. officinalis and it was primarily used for the treatment of rheumatism, paralysis, asthma, skin diseases and ulcers (Kathiresan and Ramanathan 1997, Ramanathan 2000).

The Avicennia gender has two species in Brazil, Avicennia schaueriana and Avicennia germinans (Profice et al. 2010). The Avicennia schaueriana, popularly known as black-mangrove or siriúba, is an endemic species from mangrove belonging to the family Verbenaceae (SchaefferNovelli 1995). The extract of those plant showed antibacterial activity against Staphylococcus aureus (ATTC 6835), Micrococcus luteus (ATCC 9341) and Klebsiella pneumoniae (ATCC 700603) 
(Santos et al. 2010). Furthermore, A. schaueriana proved to be promising for isolation of substances with antifungal potential (Fardin and Young 2015).

The species of the Avicennia gender are widely used by traditional communities for several diseases (Santos et al. 2010); however, there are still no scientific reports on the wound healing potential of the plant. The aim of this study was to evaluate the cytotoxicity in vitro and the wound healing activity of Aqueous Extract of Leaves of Avicennia schaueriana (AELAs) in cream on skin lesions in mice.

\section{MATERIALS AND METHODS}

BIOLOGICAL MATERIAL

Plant

The leaves of Avicennia schaueriana species were collected in October 2013, in Itamaracá mangrove, located in Vila Velha, Northern coast of the State of Pernambuco, Brazil, LAT 0 $7^{\circ} 48.716^{\prime}$ S and LONG $34^{\circ} 51.347^{\prime} \mathrm{W}$. A voucher specimen was deposited at Geraldo Mariz Herbarium in the Universidade Federal de Pernambuco (UFPE) under the registration number UFP 75.458 .

\section{Cell culture}

Vero cells (fibroblasts) from kidney of African green monkey or old world monkey (Cercopithecus aethiops) were used. The cell line (CCL-81, Rio de Janeiro, Brazil) was obtained from the Department of Histology and Embryology (UFPE). Vero cells were grown in Eagle culture medium Modified by Dulbeco (DMEM - Sigma Chemical Co., St. Louis, MO, USA) supplemented with $10 \%$ of Fetal Bovine Serum and $1 \%$ of antibiotic-antimycotic solution (10,000 units of penicillin, $10 \mathrm{mg}$ of streptomycin in $0.9 \%$ of sodium chloride; Sigma). They were maintained at $37{ }^{\circ} \mathrm{C}$ in humidified atmosphere with $5 \%$ of $\mathrm{CO}_{2}$.

\section{Experimental animals}

Forty five Wistar female mice aged 8 and 12 weeks, weighing $230 \pm 20 \mathrm{~g}$ were used. They were obtained from the Department of Antibiotics of UFPE. Experiments with animals were performed with the approval of the Ethics Committee for Animal Experimentation of the Universidade Federal de Pernambuco (UFPE) under number 23076025194/2012-10.

\section{AQUEOUS EXTRACT OF LEAVES OF A. schaueriana (AELAs)}

The aqueous extract was prepared by infusion from $500 \mathrm{~g}$ of fresh leaves of Avicennia schaueriana. The material was weighed, grounded and extracted with water at $40{ }^{\circ} \mathrm{C}$ for 20 minutes. The solid residue was removed by filtration and the water by lyophilization. The dried material was stored at $-20{ }^{\circ} \mathrm{C}$. The yield of the aqueous extract was $4 \%$ and it was used for healing and cytotoxic activity (Nascimento et al. 2016, adapted).

CREAM OF AQUEOUS EXTRACT OF LEAVES OF $A$. schaueriana (AELAs CREAM)

The AELAs was weighted on digital analytical scale (Shimadzu ATY 224) with the use of waxed paper until achieving $3 \mathrm{~g}$ and poured into porcelain mortar. It was solubilized with distilled water and homogenized. In a watch glass, the anionic emulsion was weighed until achieving $60 \mathrm{~g}$ and it was poured into the mortar containing the extract of $A$. schaueriana until solubilization. The $\mathrm{pH}$ was measured and maintained between 5.5 and 6.5. It was packed in a plastic jar containing the extract in cream at $5 \%$.

\section{CYTOTOXICITY TEST}

The evaluation of the cytotoxic activity was performed using the bromide colorimetric method (3-[4.5-dimethylthiazol-2-i1]-2.5-tetrazolium diphenyl) (MTT) (Geran et al. 1972, Mosmann 
1983). The methodology used to conduct this test followed the rules of the International Standard Organization (ISO 10993-5 2009).

The cells at the concentration of $2 \times 10^{5} / \mathrm{mL}$ of DMEM per well were distributed into 96-well plates (TPP, Darmstadt, Germany) and incubated for 24 hours at $37{ }^{\circ} \mathrm{C}$ with atmosphere enriched with $5 \%$ of $\mathrm{CO}_{2}$ and $95 \%$ of air for stabilization. After this period, the AELAs, previously dissolved in phosphate-buffered saline (PBS) and filtered ( $0.22 \mu \mathrm{m}$ syringe filter - TPP, Darmstadt, Germany) in different concentrations of $100 \mu \mathrm{g} / \mathrm{mL}, 50 \mu \mathrm{g} /$ $\mathrm{mL}, 25 \mu \mathrm{g} / \mathrm{mL}, 12.5 \mu \mathrm{g} / \mathrm{mL}$ and $6.25 \mu \mathrm{g} / \mathrm{mL}$, was added to the wells with Vero cells. PBS and DMEM culture medium were used as control. After incubation for 24 hours of contact of the cells with the extract, $25 \mu \mathrm{l}(5 \mathrm{mg} / \mathrm{mL})$ of MTT solution was added to each well and the plate was incubated for 3 hours. The MTT and culture medium were removed and $25 \mu \mathrm{l}$ of dimethylsulfoxide (DMSO) was added to each well to dissolve the formazan crystals. Subsequently, the spectrophotometer reading was performed (Bio-Rad, São Paulo, Brazil) with a wavelength of $570 \mathrm{~nm}$. The test was performed in duplicate.

\section{WOUND HEALING ACTIVITY}

\section{Division of groups}

To evaluate the wound healing activity, the mice were randomly divided into 3 groups according to the treatment proposed for the ulcers induced in each animal. The control group (15 animals) received saline solution at $0.9 \%$. The standard group (15 animals) was treated with 5\% dexpanthenol in cream and the AELAs cream group (15 animals) was treated with AELAs cream at 5\%. Each group was divided into 3 subgroups of 5 animals supervised during 5, 10 and 15 days after the induction of dorsal ulcer.

\section{Surgical procedures in vivo}

The animals were previously weighed and anesthetized with ketamine hydrochloride $(10 \mathrm{mg} /$ $\mathrm{kg}$ Ketamin $\left.{ }^{\circledR}\right)$, xylazine hydrochloride $(0.5 \mathrm{mg} / \mathrm{kg}$, Anasedan $\left({ }^{\circledR}\right.$ ) and $0.9 \%$ saline solution, associated in the same syringe and administered intramuscularly. The animals were subjected to the demarcation of the area to wound induction with subsequent trichotomy in the dorsal region and positioned on the operating table in prone position. After asepsis of the dorsal region with alcohol $70 \%$, the induction of a rectangular wound with $2.3 / 2.0 \mathrm{~cm}$ was conducted on dorsal region. A skin fragment was removed from the center of the shaved area to display the dorsal muscular fascia using a \#15 scalpel (Silva et. al 2016).

\section{Post-operative}

After surgery, the mice were subjected to the corresponding treatment and they were kept in cages. The ulcers did not receive occlusive dressings. The application of the medication relating to each group was performed daily, once a day, around 11:00 a.m. until the end of the experiment. The aspect of the wound was described during the research in different groups.

On the $5^{\text {th }}$ day, the measurement was performed on the wound area (length and width) using a caliper, but without removing the skin fragment. After 10 and 15 days, measurement of the lesion area and withdrawing of the skin fragment containing the wound were conducted. The animals were anesthetized and a scalpel \#15 was used to remove surgical pieces formed by scar or skin lesion with a margin of $1 \mathrm{~cm}$ of skin around the lesion and to the dorsal musculature of the animal. The removed tissue was placed in formalin at $10 \%$ during 24 hours at room temperature and processed for light microscopy. After the fragment collection procedure, the animals were euthanized by cervical dislocation (Silva et al. 2016). 


\section{Morphometric analysis of the wound}

For the morphometric analysis, initial and final measurements for each wound in different groups and periods were performed using a caliper to calculate the rate of healing of ulcers. It was used a degree of contraction expressed in percentage by the equation proposed by Ramsey et al. (1995), where Wo is the initial area and Wi is the final area:

$\%$ of contraction $=(\mathrm{Wo}-\mathrm{Wi}) / \mathrm{Wo} \times 100$

\section{Histomorphometric study}

After fixing the removed specimens, samples were sent for processing in conventional standard of histological technique for light microscopy and embedded in paraffin. Serial sections of $5 \mu \mathrm{m}$ were stained with Hematoxylin and Eosin (HE), fitted with "entellan" and observed under an optical microscope.

Selected histological sections were viewed in a slides scanner (3DHISTECH) for capturing images. For the evaluation of re-epithelialization, the distances non epithelialized of the wounds were measured with the Pannoramic Viewer program, with an increase of $2 x$, in the samples collected from each animal with 10 days and 15 days of treatment. Moreover, fibroblast count was performed. Five fields were acquired by preparation under 40 times magnification and quantified using ImageJ 1.48 software (Zur and Klement 2015).

\section{STATISTICAL ANALYSIS}

The in vitro study data were expressed through statistical measurements: average, standard deviation, coefficient of variation, median, minimum and maximum value. The data were evaluated according to $F$ (ANOVA) test with multiple comparisons of Tukey. To verify the hypothesis of equality of variances, the F Levene test was performed.
The data from the morphometric and histomorphometric analysis and from the counting of fibroblasts were expressed as average $\pm \mathrm{SE}$ (standard error of the average) and median. In the morphometric study, we used the F (ANOVA) test on the contrast between the groups (saline solution, dexpanthenol and AELAs cream), with multiple Tukey comparisons to evaluate the contraction percentage with 5, 10 and 15 days and the t-Student test paired in the comparison between the initial and final measurements. In the histomorphometric study and in the fibroblasts counting, the data was evaluated by the Kruskal-Wallis statistical tests in the comparison between groups and Mann-Whitney for the comparison between the evaluation times (10 and 15 days). Statistical calculations were performed using the program SPSS, version 21.0, and the margin of error used in the decisions was $5.0 \%$.

\section{RESULTS}

\section{CYTOTOXICITY}

The AELAs $(25 \mu \mathrm{g} / \mathrm{mL})$ and the PBS control showed an average number of Vero cells of 0.437 and 0.438 respectively with statistical difference when compared to the AELAs concentrations of $100 \mu \mathrm{g} / \mathrm{mL}(0.686)$ and $6.25 \mu \mathrm{g} / \mathrm{mL}(0.710)(\mathrm{p}$ $<0.001)$. The AELAs $(50 \mu \mathrm{g} / \mathrm{mL}$ and $12.5 \mu \mathrm{g} /$ $\mathrm{mL}$ ) and DMEM control did not show statistical difference when compared to the other groups with average number of Vero cells of $0.567,0.626$ and 0.533 respectively.

\section{MACROSCOPIC DESCRIPTION OF WOUNDS}

During treatments in 5, 10 and 15 days it was evaluated the macroscopic aspect of the wounds (general aspect of wounds, granulation tissue and scab and scar formation). Figure 1 shows the healing process of wounds induced in mice. Digital images showed the evolution of the wound areas in different experimental times, according to the treatment. 

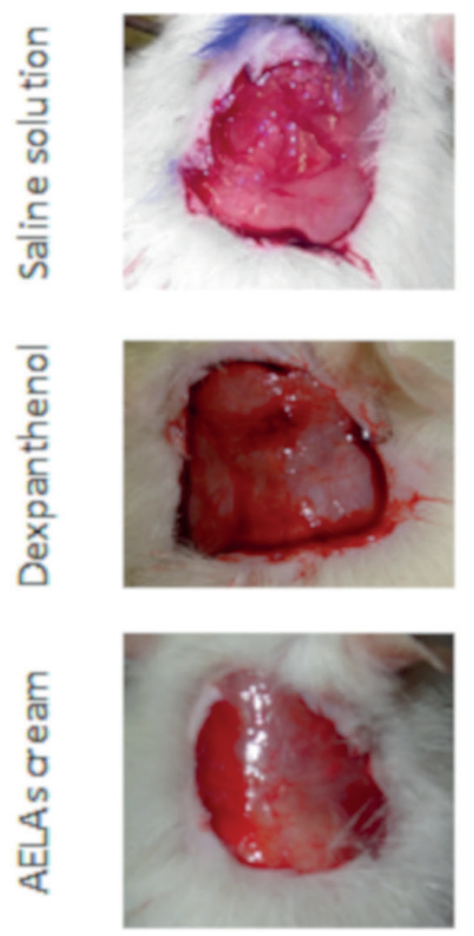

Day 0
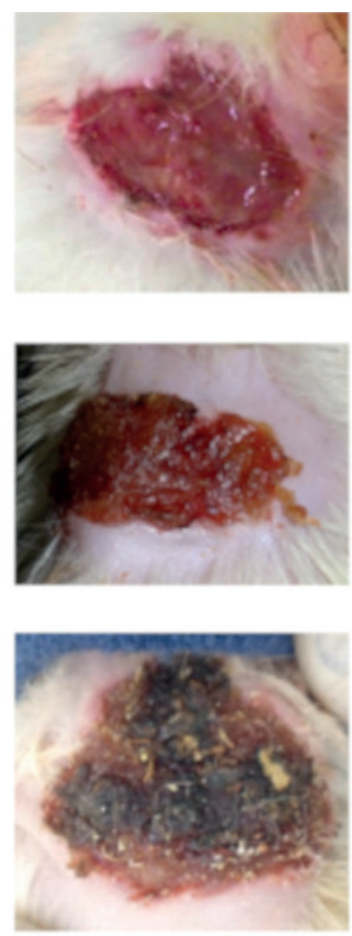

Day 5
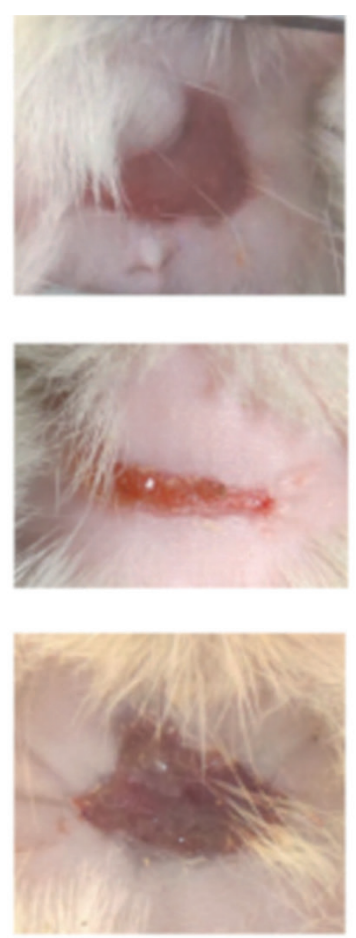

Day 10
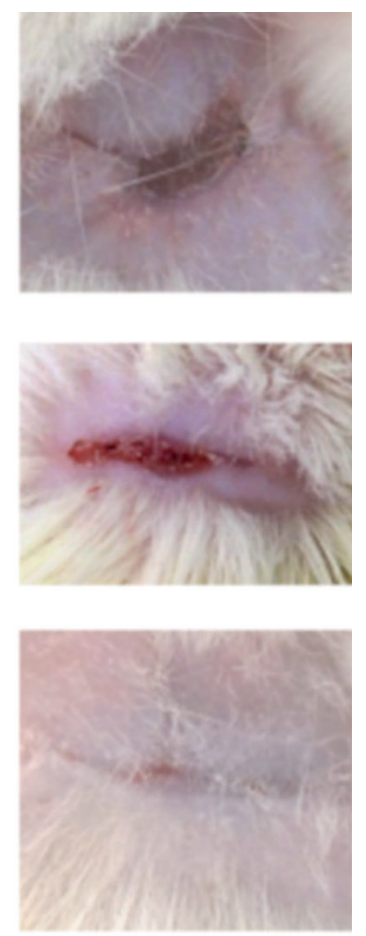

Day 15

Figure 1 - Wound healing process in different days of treatments.

The treatment with saline solution showed mice with moist infected bleeding wounds, granulation tissue from the $10^{\text {th }}$ day and scab formation in 3 mice in 15 days. The dexpanthenol group showed two mice with infected wounds in 5 days of treatment, granulation tissue from the $5^{\text {th }}$ day and scab formation in 10 days with presence of tissue granulation. The AELAs cream group in 5 days of treatment showed the presence of tissue granulation and it did not show infected wounds. In 10 and 15 days, there was an evolution to scab and scar formation in all mice.

\section{MORPHOMETRIC ANALYSIS OF THE WOUNDS}

Table I shows the average of the decreasing wound areas and an increase of wound contraction in each group. In the evaluation after 10 days, the group treated with dexpanthenol showed the lowest area $\left(30.30 \mathrm{~mm}^{2}\right)$ with the average percentage of contraction of $93.41 \%(\mathrm{p} \leq 0.05)$. However, in the analysis after 15 days, the average of the area was $25.70 \mathrm{~mm}^{2}$ with the lowest average percentage of contraction (94.41\%). The treatment with AELAs cream in 15 days showed the lowest area $\left(6.90 \mathrm{~mm}^{2}\right)$ with the highest average percentage of contraction $(98.50 \%)$ with statistical significant difference between those two groups $(\mathrm{p} \leq 0.05)$.

\section{HISTOMORPHOMETRIC ANALYSIS AND FIBROBLAST COUNTING}

Table II highlights that in 10 days, the average distance between the epithelia of the surgical wound was higher in the saline solution group (3498.66 $\mu \mathrm{m})$ with $\mathrm{p} \leq 0.05$. The lowest average was observed in the dexpanthenol group (706.28 $\mu \mathrm{m})$ with no statistical difference when compared with AELAs cream group $(833.04 \mu \mathrm{m})$. After 15 days, in all studied groups, it was verified that the average of distances between the epithelia 
TABLE I

Measurements of wound areas $\left(\mathrm{mm}^{2}\right)$ and percentage of wound contraction according to the groups and time of evaluation after in vivo surgical procedure.

\begin{tabular}{|c|c|c|c|c|}
\hline $\begin{array}{l}\text { Evaluation time after } \\
\text { wound induction }\end{array}$ & $\begin{array}{l}\text { AELAs cream }(\mathbf{n}=15) \\
\text { Average + EPM } \\
\text { (Median) }\end{array}$ & $\begin{array}{l}\text { Saline Solution }(\mathrm{n}=15) \\
\text { Average + EPM } \\
\text { (Median) }\end{array}$ & $\begin{array}{l}\text { Dexpanthenol } \\
(\mathrm{n}=15) \\
\text { Average }+ \text { EPM } \\
\text { (Median) }\end{array}$ & p value \\
\hline Initial & $\begin{array}{c}460.00 \pm 0.00 \\
(460.00)\end{array}$ & $\begin{array}{c}460.00 \pm 0.00 \\
(460.00)\end{array}$ & $\begin{array}{c}460.00 \pm 0.00 \\
(460.00)\end{array}$ & \\
\hline 5 days & $\begin{array}{c}262.30 \pm 22.98 \\
(256.50)\end{array}$ & $\begin{array}{c}227.60 \pm 22.55 \\
(230.00)\end{array}$ & $\begin{array}{c}238.04 \pm 39.05 \\
(260.00)\end{array}$ & $\mathrm{p}^{(1)}=0.698$ \\
\hline 10 days & $\begin{array}{c}93.31 \pm 10.41^{(\mathrm{A})} \\
(97.50)\end{array}$ & $\begin{array}{c}93.60 \pm 17.22^{(\mathrm{A})} \\
(88.00)\end{array}$ & $\begin{array}{c}30.30 \pm 4.29^{(\mathrm{B})} \\
(34.00)\end{array}$ & $\mathrm{p}^{(1)}=0.003^{*}$ \\
\hline 15 days & $\begin{array}{c}6.90 \pm 2.98^{(\mathrm{A})} \\
(8.00)\end{array}$ & $\begin{array}{c}17.71 \pm 3.81^{(\mathrm{AB})} \\
(16.00)\end{array}$ & $\begin{array}{c}25.70 \pm 3.47^{(\mathrm{B})} \\
(24.00)\end{array}$ & $\mathrm{p}^{(1)}=0.008^{*}$ \\
\hline p value & $\begin{array}{l}\mathrm{p}^{(2)}=0.001^{*} \\
\mathrm{p}^{(3)}<0.001^{*} \\
\mathrm{p}^{(4)}<0.001^{*}\end{array}$ & $\begin{array}{l}\mathrm{p}^{(2)}=0.001^{*} \\
\mathrm{p}^{(3)}<0.001^{*} \\
\mathrm{p}^{(4)}<0.001^{*}\end{array}$ & $\begin{array}{l}\mathrm{p}^{(2)}=0.005^{*} \\
\mathrm{p}^{(3)}<0.001^{*} \\
\mathrm{p}^{(4)}<0.001^{*}\end{array}$ & \\
\hline $\begin{array}{c}\text { Contraction \% with } 5 \\
\text { days }\end{array}$ & $\begin{array}{c}42.98 \pm 4.99 \\
(44.24)\end{array}$ & $\begin{array}{c}50.52 \pm 4.90 \\
(50.00)\end{array}$ & $\begin{array}{c}48.25 \pm 8.49 \\
(43.48)\end{array}$ & $\mathrm{p}^{(1)}=0.698$ \\
\hline $\begin{array}{c}\text { Contraction \% with } 10 \\
\text { days }\end{array}$ & $\begin{array}{c}79.72 \pm 2.26^{(\mathrm{A})} \\
(78.80)\end{array}$ & $\begin{array}{c}79.65 \pm 4.74^{(\mathrm{A})} \\
(80.87)\end{array}$ & $\begin{array}{c}93.41 \pm 0.93^{(\mathrm{B})} \\
(92.60)\end{array}$ & $\mathrm{p}^{(1)}=0.003^{*}$ \\
\hline $\begin{array}{c}\text { Contraction \% with } 15 \\
\text { days }\end{array}$ & $\begin{array}{c}98.50 \pm 0.65^{(\mathrm{A})} \\
(98.26)\end{array}$ & $\begin{array}{c}96.15 \pm 0.83^{(\mathrm{AB})} \\
(96.52)\end{array}$ & $\begin{array}{c}94.41 \pm 0.75^{(\mathrm{B})} \\
(94.78)\end{array}$ & $\mathrm{p}^{(1)}=0.008^{*}$ \\
\hline
\end{tabular}

(*): Significant difference $\leq 5 \%$. (1): Through the F (ANOVA) test for comparison between the groups in each evaluation and for the concentration percentage with 5 days, 10 days and 15 days with Tukey comparisons. (2): Through t-Student test paired for comparisons between the evaluation of initial time and 5 days in each group. (3): Through t-Student test paired for comparisons between the evaluation of initial time and 10 days in each group. (4): Through t-Student test paired for comparisons between the evaluation of initial time and 15 days in each group. Note: The different letters in brackets indicate significant differences between the corresponding groups. 
TABLE II

Distance between the epithelia of the surgical wound of the groups in relation to the evaluation time after in vivo surgical procedure.

\begin{tabular}{|c|c|c|c|c|}
\hline $\begin{array}{l}\text { Evaluation time after } \\
\text { wound induction }\end{array}$ & $\begin{array}{l}\text { AELAs cream } \\
\qquad(n=10) \\
\text { Average }+ \text { EPM } \\
\text { (Median) }\end{array}$ & $\begin{array}{c}\text { Saline solution }(\mathrm{n}=10) \\
\text { Average + EPM } \\
\text { (Median) }\end{array}$ & $\begin{array}{l}\text { Dexpanthenol } \\
\qquad(n=10) \\
\text { Average + EPM } \\
\text { (Median) }\end{array}$ & p value \\
\hline 10 days & $\begin{array}{c}833.04 \pm 515.65^{(\mathrm{A})} \\
(0.00)\end{array}$ & $\begin{array}{c}3498.66 \pm 232.37^{(\mathrm{B})} \\
(3572.98)\end{array}$ & $\begin{array}{c}706.28 \pm 233.73^{(\mathrm{A})} \\
(704.84)\end{array}$ & $\mathrm{p}^{(1)}=0.002^{*}$ \\
\hline 15 days & $\begin{array}{l}0.00 \pm 0.00 \\
\quad(0.00)\end{array}$ & $\begin{array}{c}968.89 \pm 303.49 \\
(905.04)\end{array}$ & $\begin{array}{c}582.21 \pm 370.34 \\
(0.00)\end{array}$ & $\mathrm{p}^{(1)}=0.078$ \\
\hline p value & $\mathrm{p}^{(2)}=0.444$ & $\mathrm{p}^{(2)}=0.008^{*}$ & $\mathrm{p}^{(2)}=0.683$ & \\
\hline
\end{tabular}

(*): Significant difference $\leq 5 \%$. (1): Through the Kruskal-Wallis test for comparisons between the groups in each evaluation time with comparisons of the mentioned test. (2): Through Mann-Whitney test for comparisons between evaluation time in each group. Note: The different letters in brackets indicate significant differences between the corresponding groups.

were correspondingly smaller than after 10 days, indicating an increase in re-epithelialization. The saline solution group showed the highest distance. In 15 days, the average of distance between the epithelia of the surgical wound in AELAs cream group was null, indicating complete re-epithelialization of the wounds in all mice (Figure 2).

In Table III it is verified that within 10 days, the average of fibroblasts were higher in AELAs group (579.20) than the saline solution group (295.20) (p $\leq 0.05)$. In the evaluation performed after 15 days of the wound induction, the average number of fibroblasts in AELAs cream group remained higher (568.40) compared to the others $(\mathrm{p} \leq 0.05)$.

\section{DISCUSSION}

Wound healing is a dynamic and interactive process initiated in response to an injury (Guo and Dipietro 2010), whose purpose is to restore the anatomical and functional continuity of the tissue. The process is essential for maintaining the body integrity (Barbul 1990, Broughton et al. 2006, Thornton et al. 1997). A large number of investigations and clinical trials have been conducted with the aim of improving the healing process of wounds (Das 2013, Duarte et al. 2011, Gál et al. 2009, Li et al. 2015, Ulger et al. 2016) and consequently quality of life.

This is the first study that addresses the therapeutic potential in relation to the healing of the Avicennia schaueriana species. It is important to note that the Avicennia gender has chemical constituents that may have different pharmacological properties, such as alkaloids, tannins, flavonoids, saponins and triterpenes (Abeysinghe 2010, Ghani 1998, Vadlapudi 2012), which contribute to the medicinal activity of the plant.

According to ISO 10993-1 (2018), the in vitro cytotoxicity test is one of the tests that serves to evaluate the biocompatibility of a particular material or extract, showing an important step for animal testing and clinical trials. The results of this research show that the Aqueous extract of leaves of Avicennia schaueriana (AELAs) did not show cytotoxic activity, since in all tested concentrations there was Vero cells proliferation. Studies with 


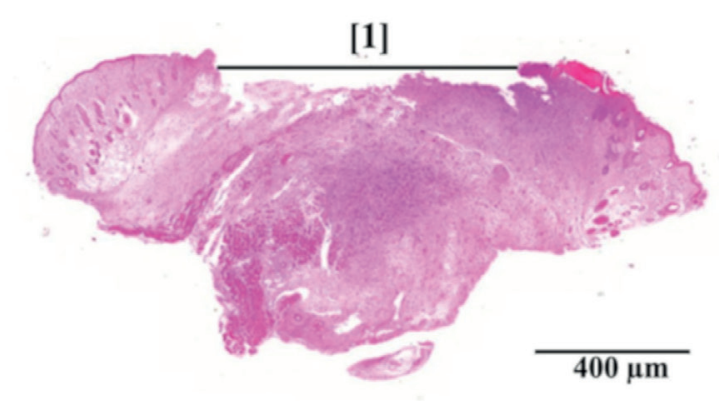

(a)

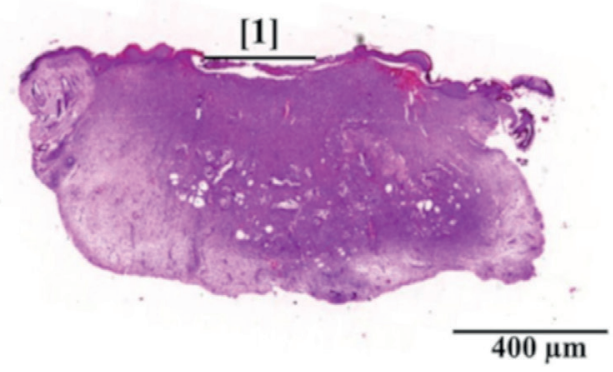

(b)

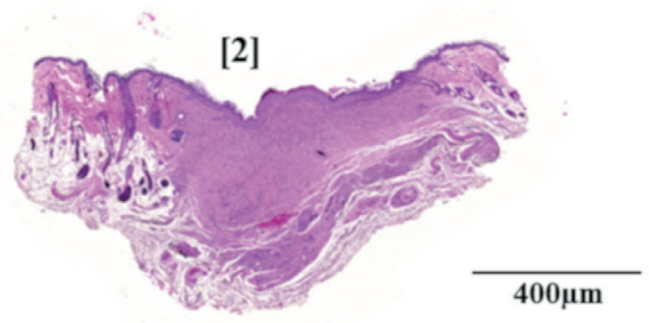

(c)

Figure 2 - Histological Sections of dorsal skin of mice showing the saline solution group (a), dexpanthenol group (b) and AELAs cream group (c). All images show the extent of re-epithelialization after 15 days of treatment: [1] distance between the epithelium and [2] total re-epithelialization. HE staining. Magnification 20x.

some species of the Verbenaceae family showed similar results. Akter et al. (2014), using a methanol extract of the leaves of $A$. alba, showed that this plant has an antitumor potential by cytotoxicity against cancer cells, however, it did not show cytotoxic activity on Vero cells. Behbahani et al. (2013) concluded that the methanolic extract of $A$. marina did not affect the viability of Vero cells, demonstrating no cytotoxic effect at concentrations equal to or less than $32 \mu \mathrm{g} / \mathrm{mL}$. According to Bueno et al. (2014), tannins influence on the physiology of skin cells through their pharmacological properties, increasing cell proliferation. The result of this study suggests a mitogenic activity of AELAs possibly because of tannins presence.

In inspection of the surgical wounds, it was observed that the groups of saline solution and dexpanthenol showed scabs and granulation tissue with infectious processes of the wounds during the study period. However, the group of AELAs cream showed scabs and scars without infection in surgical wound. The results can be explained by different mechanisms of action of secondary compounds present in the plant, such as tannins and flavonoids, which are known to have antimicrobial and antioxidant properties (Ofori-Kwakye et al. 2011). Therefore, Santos et al. (2010) showed that the hydro-alcoholic extracts of the bark, leaves and roots of $A$. schaueriana showed antibacterial activity in vitro, which can contribute to the healing activity of this plant, reducing the risk of infection of the injury, which is the most likely cause of the delay in wound healing (Leaper et al. 2015).

The morphometric analysis revealed that the average of the wound areas decreased with the progression of evaluation time in all groups. It was observed that the dexpanthenol cream had an excellent performance in the healing of skin injuries of mice in the first 10 days compared to the other groups. Dexpanthenol cream is widely used because it indicates improvement in wound healing (Heise et al. 2012, Oguz et al. 2015, Ulger et al. 2016), since it easily penetrates the skin in high local concentrations. The most significant effects of formulations containing dexpanthenol include stimulation of epithelialization, granulation and itching relief (Ebner et al. 2002). However, after 15 days of treatment the AELAs cream group showed the highest percentage of wound healing. The studied plant significantly stimulated contraction of the wound, accelerating the healing process. This healing property is probably due to the high content 
TABLE III

Fibroblast counting after in vivo surgical procedure in 10 and 15 days.

\begin{tabular}{|c|c|c|c|c|}
\hline \multirow{3}{*}{$\begin{array}{l}\text { Evaluation time after } \\
\text { wound induction }\end{array}$} & AELAs cream $(n=10)$ & Saline solution $(n=10)$ & $\begin{array}{c}\text { Dexpanthenol } \\
(\mathrm{n}=10)\end{array}$ & \multirow{3}{*}{ p value } \\
\hline & Average + EPM & Average + EPM & Average + EPM & \\
\hline & (Median) & (Median) & (Median) & \\
\hline \multirow[t]{2}{*}{10 days } & $579.20 \pm 60.67^{(\mathrm{A})}$ & $295.20 \pm 26.47^{\text {(B) }}$ & $508.60 \pm 46.83^{(\mathrm{A})}$ & $\mathrm{p}^{(1)}=0.004^{*}$ \\
\hline & $(527.00)$ & $(276.00)$ & $(537.00)$ & \\
\hline \multirow[t]{2}{*}{15 days } & $568.40 \pm 53.60^{(\mathrm{A})}$ & $331.00 \pm 35.57^{(\mathrm{B})}$ & $397.00 \pm 45.40^{(\mathrm{B})}$ & $\mathrm{p}^{(1)}=0.011^{*}$ \\
\hline & $(543.00)$ & $(338.00)$ & $(421.00)$ & \\
\hline p value & $\mathrm{p}^{(2)}=1.000$ & $\mathrm{p}^{(2)}=0.421$ & $\mathrm{p}^{(2)}=0.222$ & \\
\hline
\end{tabular}

(*): Significant difference $\leq 5 \%$. (1): Through Kruskal-Wallis test for comparisons between the groups in each evaluation time with comparisons of the mentioned test. (2): Through Mann-Whitney test for comparisons between evaluation time in each group. Note: The different letters in brackets indicate significant differences between the corresponding groups.

of flavonoids (Vinothapooshan and Sundhar 2010), saponins (Jiang et al. 1991) and tannins present in the plant, because these secondary compounds have astringent and antimicrobial characteristics, which appear to be responsible for wound contraction and epithelialization rate increase (Deshmukh et al. 2009).

In the histomorphometric analysis, the average distance between the epithelia of the surgical wound was significantly higher in the group of saline solution after 10 days, and similar between the groups treated with dexpanthenol and AELAs cream. In the evaluation after 15 days of treatment, all animals treated with AELAs cream showed complete re-epithelialization of wounds. This can be attributed to the presence of tannins in this plant, because they contribute to the formation of a protective layer on the skin and mucous membranes, acting in inflammatory processes, causing the epithelium restructuring and neovascularization (Simões et al. 2010). This layer can exert a protective action isolating the wound from the environment, accelerating, significantly, the tissue repair in the group treated with the AELAs cream.

Additionally, in this study, there was a significant increase in the amount of fibroblasts in AELAs cream group compared to the other groups in 15 days. Ulger et al. (2016) believe that the improvement in wound healing rate is due to the increased proliferation of fibroblasts, as well as a rapid epithelization. In addition, other studies show the importance of fibroblasts in the healing process (Das 2013, Diegelmann and Evans 2004, Ebner et al. 2002, Khoshneviszadeh et al. 2014, Sonmez et al. 2015). It is suggested that this stimulatory activity of dermal fibroblasts in the group of the studied plant is due to the presence of hydrolyzable tannins (Bueno et al. 2014).

Therefore, we emphasize the importance of histomorphometry in the studies, since only from the microscopic analysis was possible to evaluate the degree of re-epithelialization of the wound, showing that the groups treated with dexpanthenol and AELAs cream were superior to the saline solution because they obtained a faster and more efficient healing process. In all analyzed groups, the 
one that obtained the best results of healing was the AELAs cream group. However, several studies are still necessary to evaluate the medical potential of this plant.

\section{CONCLUSIONS}

This study showed that the $A$. schaueriana species did not show cytotoxic activity. In addition, topical application of the AELAs cream decreases the area of the wound, stimulates re-epithelialization and increases the number of fibroblasts, exhibiting a healing activity on skin injuries in mice more efficient than dexpanthenol cream. Therefore, new researches on this plant could contribute to a topical treatment in tissue repair process with benefits to the population.

\section{ACKNOWLEDGMENTS}

To Universidade Federal de Pernambuco (UFPE), the Department of Histology and Embryology from CCB/UFPE, the Department of Antibiotics from CCB/UFPE, and the Coordenação de Aperfeiçoamento de Pessoal de Nível Superior (CAPES) for the financial support.

\section{AUTHOR CONTRIBUTIONS}

All authors made substantive intellectual contributions to the manuscript. Briefly, Caroline Maria Igrejas Lopes, Ivone Antônia de Souza, Erwelly Barros de Oliveira, Jéssica Guido de Araújo Sá, Marllon Alex Nascimento Santana and Pedro Paulo Marcelino Neto participated in the execution of the research and in the planning, analysis and preparation of the manuscript; Liriane BaratellaEvêncio supervised the project and participated in the planning, analysis and preparation of the manuscript; Eduarda Santos de Santana and Luzia Abílio da Silva contributed to the preparation of the manuscript; finally, Jeymesson Raphael Cardoso Vieira conceived the original idea, contributed to the methodological design and participated in the analysis of the results and critical review of the manuscript.

\section{REFERENCES}

ABEYSINGHE PD. 2010. Antibacterial Activity of some Medicinal Mangroves against Antibiotic Resistant Pathogenic Bacteria. Indian J Pharm Sci 72: 167-172.

AGORAMOORTHY G, CHANDRASEKARAN M, VENKATESALU V AND HSU MJ. 2007. Antibacterial and antifungal activities of fatty acid methyl esters of the blind-your eye mangrove from India. Braz J Microbiol 38: 739-742.

AGRA MF, FREITAS PF AND BARBOSA-FILHO JM. 2007. Synopsis of the plants known as medicinal and poisonous in Northeast of Brazil. Rev Bras Farmacogn 17: 114-140.

AKTER R, UDDIN SJ, GRICE ID AND TIRALONGO E. 2014. Cytotoxic activity screening of Bangladeshi medicinal plant extracts. J Nat Med 68: 246-252.

BANDARANAYAKE WM. 1998. Traditional and medicinal uses of mangroves. Mangroves and Salt Marshes 2: 133148.

BARBUL A. 1990. Immune aspects of wound repair. Clin Plast Surg 17: 433-442.

BARRIENTOS S, STOJADINOVIC O, GOLINKO MS, BREM H AND TOMIC-CANIC MS. 2008. Growth factors and cytokines in wound healing. Wound Repair Regen 16: 585-601.

BEHBAHANI M, ZADEH MS AND MOHABATKAR H. 2013. Evaluation of antiherpetic activity of crude extract and fractions of Avicenna marina, in vitro. Antiviral Res 97: 376-380.

BROUGHTON G, JANIS JE AND ATTINGER CE. 2006. Wound healing: an overview. Plast Reconstr Surg 117: $1-32$.

BUENO FG, PANIZZON GP, MELLO EV, LECHTENBERG M, PETEREIT F, DE MELLO JC AND HENSEL A. 2014. Hydrolyzable tannins from hydroalcoholic extract from Poincianella pluviosa stem bark and its wound-healing properties: phytochemical investigations and influence on in vitro cell physiology of human keratinocytes and dermal fibroblasts. Fitoterapia 99: 252-260.

CAMPOS ACL, BORGES-BRANCO A AND GROTH AK. 2007. Cicatrização de feridas. Arq Bras Cir Dig 20: 51-58.

CLARK RAF. 2005. Wound repair. In: Robbins and Cotran, Pathologic Basis of Disease, $7^{\text {th }}$ ed., Saunders, $112 \mathrm{p}$.

DAS K. 2013. Wound healing potential of aqueous crude extract of Stevia rebaudiana in mice. Braz J Pharmacog 23: 351-357.

DESHMUKH PT, FERNANDES J, AKARTE A AND EMMANUEL T. 2009. Wound healing activity of 
Calotropis gigantea root bark in rats. J Ethnopharmacol 125: 178-181.

DIEGELMANN RF AND EVANS MC. 2004. Wound healing: an overview of acute, fibrotic and delayed healing. Front Biosci 9: 283-289.

DUARTE CME, QUIRINO MRS, PATROCÍNIO MC AND ANBINDER AL. 2011. Effects of Chamomilla recutita (L.) on oral wound healing in rats. Med Oral Patol Oral Cir Bucal 16: 716-721.

EBNER F, HELLER A, RIPPKE F AND TAUSCH I. 2002. Topical use of dexpanthenol in skin disorders. Am J Clin Dermatol 3: 427-433.

FARDIN KM AND YOUNG MC. 2015. Antifungal potential of Avicennia schaueriana stapf \& leech. (acanthaceae) against cladosporium and colletotrichum species. Lett Appl Microbiol 61: 50-57.

GÁL P ET AL. 2009. Effect of Atropa belladonna L. on skin wound healing: biomechanical and histological study in rats and in vitro study in keratinocytes, 3T3 fibroblasts, and human umbilical vein endothelial cells. Wound Repair Regen 17: 378-386.

GAZIM ZC, REZENDE CM, FRAGA SR, SVIDZINSKI TI AND CORTEZ DA. 2008. Antibacterial activity of the essential oil from Calendula officinalis L. (Asteracea) growing in Brazil. Braz J Microbiol 39: 61-63.

GERAN RI, GREENBERG NH AND MAC DONALD MM. 1972. Protocols for screening chemical agents and natural products against animal tumors and other biological systems. Cancer Chemother Rep 3: 208-209.

GHANI A. 1998. Medicinal Plants of Bangladesh: Chemical constituents and uses. Asiatic Society of Bangladesh, p. 212-216.

GUO S AND DIPIETRO LA. 2010. Factors affecting wound healing. J Dent Res 89: 219-229.

GURTNER GC, WERNER S, BARRANDON Y AND LONGAKER MT. 2008. Wound repair and regeneration. Nature 453: 314-321.

HEISE R ET AL. 2012. Dexpanthenol modulates gene expression in skin wound healing in vivo. Skin Pharmacol Physiol 25: 241-248.

ISO 10993-1. 2018. International standard: Biological evaluation of medical devices Part 1: Evaluation and testing within a risk management process, $40 \mathrm{p}$.

ISO 10993-5. 2009. International standard: Biological Evaluation of Medical Devices Part 5: Tests for Cytotoxicity: in vitro methods, $34 \mathrm{p}$.

JIANG Y, HAAG-BERRURRIER M AND ANTION R. 1991. Structure of a new saponin from the bark of Mimosa tenuiflora. J Nat Prod 54: 1247-1253.

KATHIRESAN K AND RAMANATHAN T. 1997. Medicinal Plants of Parangipettai Coast. Monograph, Annamalai University, India, 76 p. (Unpublished).
KHOSHNEVISZADEH M, ASHKANI-ESFAHANI S, NAMAZI MR, NOORAFSHAN A, GERAMIZADEH B AND MIRI R. 2014. Topical Simvastatin Enhances Tissue Regeneration in Full-thickness Skin wounds in rat models. Iran J Pharm Res 13: 263-269.

KIM H, KAWAZOE T, HAN DW, MATSUMARA K, SUZUKI S, TSUTSUMI S AND HYON SH. 2008. Enhanced wound healing by an epigallocatechin gallate-incorporated collagen sponge in diabetic mice. Wound Repair Regen 16: 714-720.

LEAPER D, ASSADIAN O AND EDMISTON CE. 2015. Approach to chronic wound infections. Br J Dermatol 173 : 351-358.

LI X, WANG H, RONG H, LI W, LUO Y, TIAN K, QUAN D, WANG Y AND JIANG L. 2015. Effect of composite SiO2@AuNPs on wound healing: in vitro and vivo studies. J Colloid Interface Sci 445: 312-319.

MOSMANN T. 1983. Rapid colorimetric assay for cellular growth and survival: application to proliferation and cytotoxicity assays. J Immunol Methods 65: 55-63.

NASCIMENTO DKD, SOUZA IA, OLIVEIRA AFM, BARBOSA MO, SANTANA MAN, PEREIRA JÚNIOR DF, LIRA EC AND VIEIRA JRC. 2016. Phytochemical Screening and Acute Toxicity of Aqueous Extract of Leaves of Conocarpus erectus Linnaeus in Swiss Albino Mice. An Acad Bras Cienc 88: 1431-1437.

NASCIMENTO GGF, LOCATELLI J, FREITAS PC AND SILVA GL. 2000. Antibacterial activity of plant extracts and phytochemicals on antibiotic resistant bacteria. Braz $\mathrm{J}$ Microbiol 31: 247-256.

OFORI-KWAKYE K, KWAPONG AA AND BAYOR MT. 2011. Wound healing potential of methanol extract of Spathodea campanulata stem bark formulated into a topical preparation. Afr J Tradit Complement Altern Med 8: 218-223.

OGUZ A, USLUKAYA O, ALABALIK U, TURKOGLU A, KAPAN M AND BOZDAG Z. 2015. Topical $\mathrm{N}$-acetylcysteine improves wound healing comparable to dexpanthenol: an experimental study. Int Surg 100: 656661.

PANDA SK, THATOI HN AND DUTTA SK. 2009. Antibacterial activity and phytochemical screening of leaf and bark extracts of Vitex negundo L. from Similipal biosphere reserve, Orissa. J Med Plant Res 3: 294-300.

PROFICE SR, KAMEYAMA C, CÔRTES ALA, BRAZ DM, INDRIUNAS A AND VILAR T. 2010. Acanthaceae. In: Lista de Espécies da Flora do Brasil. Jardim Botânico do Rio de Janeiro, $871 \mathrm{p}$.

RAMANATHAN T. 2000. Studies of Medicinal Plants of Parangipettai Coast (South East Coast of India), 181 p. Ph.D. thesis, Annamalai University, India.

RAMSEY DT, POPE ER, WAGNER-MANN C, BERG JN AND SWAIN SF. 1995. Effects of three occlusive dressing 
materials on healing of full thickness skin wounds in dogs. Am J Vet Res 56: 941-949.

ROLSTAD BS, BRYANT RA AND NIX DP. 2012. Topical management. In: Bryant RA and Nix DP (Eds), Acute and chronic wounds: current management concepts, $4^{\text {th }}$ ed., Missouri: Elsevier Mosby, p. 289-306.

ROSS R. 1969. Wound healing. Sci Am 220: 40-50.

SANTOS SC, FERREIRA FS, DAMIÃO AO, DAMIÃO AO, BARROS TF, ROSSI-ALVA JC AND FERNANDEZ LG. 2010. Avaliação da atividade antibacteriana dos extratos de Avicennia schaueriana Stapf \& Leechm. ex Moldenke, Verbenaceae. Rev Bras Farmacogn 20: 124-129.

SCHAEFFER-NOVELLI Y. 1995. Manguezal: ecossistema entre a terra e o mar, $1^{\mathrm{a}}$ ed., São Paulo: Caribbean ecological research, $64 \mathrm{p}$.

SILVA EV ET AL. 2016. Antinociceptive and healing activity of the methanolic and hydroethanolic extracts of Caulerpa taxifolia. Afr J Pharm Pharmacol 10: 565-570.

SILVA MIG, GONDIM APS, NUNES IFS AND SOUSA FCF. 2006. Utilização de fitoterápicos nas unidades básicas de atenção à Saúde da Família no município de Maracanaú (CE). Rev Bras Farmacogn 16: 455-462.

SIMÕES CMO, SCHENKELEP, GOSMANN G, MELLO JCP, AULER L AND PETROVICK PR. 2010. Farmacognosia: da Planta ao Medicamento, $6^{\mathrm{a}}$ ed., Porto Alegre/ Florianópolis: Universidade UFRGS / UFSC, 1104 p.
SONMEZ E, TURKDOGAN KA, CIVELEK C, DUR A, GULEN B, KARAYEL E, GUCIN Z AND SOGUT O. 2015. The efficacy of absorbable polysaccharide haemostats in wound healing. Blood Coagul Fibrinolysis 26: 50-53.

SUMITHRA M, JANJANAM VK AND KANCHARANA VS. 2011. Influence of methanolic extract of Avicennia officinalis leaves on acute, subacute and chronic inflammatory models. Int J Pharmtech Res 3: 763-768.

THORNTON FJ, SCHÄFFER MR AND BARBUL A. 1997. Wound healing in sepsis and trauma. Shock 8: 391-401.

ULGER BV, KAPAN M, USLUKAYA O, BOZDAG Z, TURKOGLU A, ALABALIK U AND ONDER A. 2016. Comparing the effects of nebivolol and dexpanthenol on wound healing: an experimental study. Int Wound J 13: 367-371.

VADLAPUDI V. 2012. In vitro antimicrobial activity of plant extracts of Avicennia alba against some important pathogens. Asian Pac J Trop Dis 2: 408-411.

VINOTHAPOOSHAN G AND SUNDHAR K. 2010. Wound healing effect of various extracts of Adhatoda vasica. Int $\mathrm{J}$ Pharm Bio Sci 1: 530-536.

ZUR G AND KLEMENT E. 2015. Use of ImageJ software for histomorphometric evaluation of normal and severely affected canine ear canals. Can J Vet Res 79: 316-322. 